\title{
Investigating Pre-service Mathematics Teachers' Innovation Awareness and Views Regarding Intelligent Tutoring Systems
}

\author{
Mustafa Erdemir ${ }^{1}$, Şebnem Kandil İngeç, ${ }^{2, *}$ \\ ${ }^{1}$ Department of Mathematics and Science Education, Education Faculty, Kastamonu University, Turkey \\ ${ }^{2}$ Teacher Training in Physics, Gazi Education Faculty, Gazi University, 06500, Ankara, Turkey
}

Copyright $\subseteq 2016$ by authors, all rights reserved. Authors agree that this article remains permanently open access under the terms of the Creative Commons Attribution License 4.0 International License

\begin{abstract}
The purpose of this study is to identify pre-service primary mathematics teachers' views regarding on Web-based Intelligent Tutoring Systems (WBITS) in relation to its usability and influence on teaching. A survey method was used. The study was conducted with 43 students attending the mathematics teaching program under the department of elementary education. The data were collected through a paper-based survey composed of three parts. In the first part of the survey, there are 9 items about demographic information demographic profile of the respondents such as name, gender, age, study styles, learning styles, and motivation styles. In the second part, there is a scale about "Innovation Awareness Scale" and in the third part there is a scale about views concerning the usability and the influence of WBITS on learning. The data obtained from the study were analyzed using SPSS-21 based on descriptive statistics such as frequency, percentage distribution, and arithmetic mean in addition to MANOVA, which is a parametric test, and "Pearson product-moment correlation coefficient". Analysis indicated that the participants were "neither negative or positive" regarding both WBITS and innovation. It was seen that there was no significant relationship between participant awareness regarding innovation and their views regarding WBITS. Another important finding is that study styles, learning styles, and motivation styles are not influential variables over their views about WBITS' usability and its effect on learning attitudes towards WBITS.
\end{abstract}

Keywords Pre-service Mathematics Teachers, Innovation, Intelligent Tutoring System

\section{Introduction}

The increased effectiveness of information technology in human life has led to changes in learning environments. Due to transition from "digital immigrant" generation to "digital native" generation, the education given to this new generation has led to the emergence of technology-based educational and instructional paradigms thanks to innovative technologies [1]. The common use of the Internet and computers in all aspects of life has made it compulsory to the Internet and computer in educational activities as well.

Today, books are replaced by the Internet and web technologies which constitute independent teaching environments. One of the most important products of these technologies is web-based learning environments. Web-based learning environments are the synthesis of distant learning, Internet/web technologies, and learning environments $[2,3]$. Learning environment is a concept to describe teaching processes, and it has a wide spectrum ranging from de facto psycho-social learning environments to environments created with computer and Internet technologies $[2,4,5]$.

Literature review highlights that teachers should take into account development psychology and learning-teaching strategies as well as individual differences while educating their students [6]. Effective teaching is carried out in learning environments where individual differences are taken into account. Web-based learning activities can create individual learning environments for students with different areas of intelligence and learning styles stemming from their individual differences for the educational process.

Intelligent Teaching Systems, which aim active education at high quality providing individual atmosphere that gives the feeling of the interaction with an expert educator, are education systems which adapted to the individuals [53]. Web-based systems applies web technology and network database technology to analysis and design. While developing web based intelligent tutoring systems, pedagogic data suitable for students and pedagogic sequence of the courses are included [54]. Web-based systems are available on central servers and allow a user to learn in her 
own environment and whenever it is appropriate for her [55]. Intelligent Teaching Systems is a direction for scientific research to the next generation.

Web-based learning activities are capable of offering more active participation-based, re-constructive, fast, and flexible learning environments. Innovative technology applications, which provide maximum support and benefit for processes in these learning environments where information flow is fast and dynamic, are widely on the increase $[7,8,9]$. In order to make use of technology during the learning process, it is important to pay attention to how technology is integrated into teaching and how it is used in practice. In this sense, it is necessary to explore how technology can be improved in a way which raises the level of learning and makes students acquire basic skills necessary for the $21^{\text {st }}$ century.

As European Expert Network on Economics of Education (EENEE) analytical report (2015); the reasons why many researchers, policy makers and educators believe in the potential of Internet-based teaching and learning methods are at least threefold: computers have the potential to allow for individualized teaching and learning; new technologies increase the transparency of student progress and allow teachers to more easily monitor and adapt to students; computers and the Internet have the potential to engage students more than traditional teaching methods do productive innovations in the classroom require teachers. Compared with the traditional tutoring system, web-based learning activities is more innovative. The success of Web-based teaching and learning methods depends on the ability of the teachers that are able to innovate. In other words, teachers play a key role in the effectiveness of a Web-based learning activities. Since today's pre-service teachers are tomorrow's teachers, their innovation awareness might affect their students' skill development. Thus, in this study our aim is to investigate the aspects of pre-service mathematics teachers' innovation awareness, who have experiences with web-based intelligent tutoring systems (WBITS), on their opinions regarding the usability of WBITS and their effect on learning.

\subsection{Education and Technology: Overview}

According to literature, technology is a valuable tool that can help to improve teaching and learning abilities $[10,11,12]$. Studies argue that learning through technology has an influence on having more meaningful personal interpretations and worldviews [13]. Moreover, it is stated that technology allows indirect, formal or informal learning as well as a combination of all [9]. To Steiner [14], technology, as a system, refers to four components in education which are teacher, learner, content and context. Six different types of relationships are established between these four components and these relationships can be reconstructed through technology. However, some studies explore the failures of information technologies in education [15]. In case of an appropriate use, technology in the classroom does not guarantee impact on student outcomes, but it can help to improve students' performance on achievement tests $[16,17]$.

The role of technology in education has been an important question in the literature [18,20-22]. Some of these studies focus on technology education [22]. Studies highlight that selecting the suitable technology and method for each learning need is important for the success of education $[9,23]$. Some studies have suggested various models for technology education such as 'education in technology', 'education about technology', and 'education for technology' [22]. The contribution of these models to science education has been explored.

Technology-centered approaches focus on technology in education while learner-centered approaches adapt technology to serve learners as a cognitive tool [9]. According to Halimatou and Yang[10], the new educational technology includes several other technologies including cognitive tools that contain semantic organization tools, dynamic modeling tools, interpretation tools, tools for building the knowledge, and conversation tools.

To Babette and Reitzes [16], the recent standards documents highlight that technology use in education is fundamental to help students build 21 st century skills. The International Society for Technology in Education [24] encourages teachers to incorporate across content areas including using technology to demonstrate creative thinking and to develop innovative products.

\subsection{Purpose and Significance of the Study}

It is stated in the literature that using information and communication technologies to have instant access to information in different places, and technology as part of life play a role in the emergence of new skills which are of importance in the information age among students $[9,25]$. Of these skills, two are creativity and innovation. The use of information and communication technologies is generally suggested as a method to improve such skills [26].

Innovation is considered as one of the ten skills which are necessary for the 21st century [27]. It involves producing new things (or replacing a material of a current product with a cheaper material), using new processes, obtaining new raw materials (or finding sources for raw and semi-manufactured materials), creating new organizational structures, and penetrating into new markets (or using better ways of marketing a product or service, or introducing new products to the market) [28]. Nowadays, it is important to perceive changes, adapt to them, and produce policies according to the changes and put them into practice [29]. In this sense, innovation is a key concept.

In today's societies, innovative thinking which is ideas and knowledge into new value is gaining importance gradually. Therefore, innovation culture should be properly planned. The most important responsibility in indoctrinating young people into innovative culture is on the shoulders of education. Innovative culture is one that supports the creation of new ideas and the implementation of those ideas. 
Teachers are the implementers of each educational innovation in the class. In this sense, identifying the innovation awareness of pre-service teachers will be beneficial since they are the educators of tomorrow.

Education is one of the most important tools for raising awareness and developing good attitudes [30]. Therefore, it is important to determine how WBITS can be used for education and how they can be adapted into education so as to raise awareness concerning innovation. There are only a limited number of studies focusing on proved outcomes regarding to what extent technology-based models have an influence on the development of new skills, which are important in the information age, in order to offer interesting and strong learning contents, sources, experiences and evaluation systems which can measure student development in a better way. Furthermore, literature highlights the question "How should technology use be improved to raise learning?" instead of "How does technology increase learning?" [31]. This study is an attempt to answer such questions in the literature.

The purpose of this study is to explore the influence of the demographic characteristics and the innovation awareness of pre-service mathematics teachers', who have experiences with web-based intelligent tutoring systems (WBITS), on their opinions regarding the usability of WBITS and their effect on learning. Questions below were tried to be answered in accordance with this general purpose.

- What are the demographic characteristics of pre-service mathematics teachers?

- What are the levels of innovation awareness of pre-service mathematics teachers?

- What are the views of pre-service mathematics teachers regarding WBITS' usability and its effect on learning?

- Is there a significant difference between pre-service mathematic teachers' views regarding WBITS by innovation awareness, study style, learning style, and motivation styles?

- Is there a significant relationship between pre-service mathematics teachers' views regarding WBITS and innovation awareness?

At this point, it is considered beneficial to make mention of intelligent tutoring systems, which were used by the participants, and their characteristics.

\subsection{Intelligent Tutoring Systems and the Characteristics of the Web-based Intelligent Tutoring System Used by the Pre-Service Mathematics Teachers}

Advancements in computer systems and artificial intelligence have led to the creation of intelligent tutoring environments. In parallel with the developments in artificial neural network, intelligent environments have been developed. Today, we have Intelligent Tutoring Systems (ITS) as well. ITS are computer-based teaching systems where teaching content and teaching strategies that determine what to teach and how to teach are modelled [32].
Graesser [33] states that ITS have student model modules which monitor students' knowledge, skills, strategies, motivation, and other learner characteristics in detail. If Intelligent Tutoring Systems are used as educational systems, they provide feedback and an individual learning environment, perceive the level of knowledge, identify the deficiencies, and put forward recommendations just like a teacher.

Intelligent Tutoring Systems adapt to the individual needs of students and teacher behaviors and aim to achieve teacher behaviors. ITS provide students with flexible teaching materials, one-to-one learning environment, and feedback [34]. Intelligent tutoring systems are currently considered as the teaching systems of future [35]. In this regenerating world, teachers and pre-service teachers, who have the capacity to shape the future, will undertake important roles [36]. In this sense, the studies dwelling on teacher views regarding WBITS and variables which are influential on views regarding WBITS are really important.

Improvements in communication technologies and the Internet have led to the emergence of Web-based Intelligent Tutoring Systems (WBITS). ITS, which are Internet-based, provide students with an educational process free from time and place. ITS provide a flexible learning environment. They allow carrying out the activities which cannot be carried out in the classes. In other words, they facilitate learning. WBITS offer an opportunity for education which is cleansed from all the problems likely to be posed by the Internet-based education [41]. It is very beneficial that students access courses through web and receive feedbacks about their performances. WBITS have the potential to save the student's mistakes which they make while solving problems since it is computer-based.

\subsection{The Characteristics of the Web-based Intelligent Tutoring System Used in the Study}

The intelligence characteristics of the web-based intelligent tutoring system used by the participants are summarized below. Characteristics cover teacher behaviors exhibited during educational activities:

- Looking at another page by skipping the current one is prevented.

- While watching the course content, pages which are allowed and not allowed to be watched are determined by the system.

- The system saves the responses given by each student to each activity, monitors how many times the student opens each page and how long s/he stays there, and reports these details to the teacher. The teacher can access such details through a screen which is for monitoring the students.

- The teacher can see which pages are covered by the student and which are not.

- The teacher can edit the responses given by the students to the activities and write comments to the students regarding their responses or the subject. 
- The student's level of watching the page (studying the page), how many times s/he enters the page, and how long s/he stays there are determined by ANN. Students who do not meet the expected level of watching the page are prevented from viewing the exam page and redirected to those pages.

- The students can take the exam after studying the pages specified by the system for an adequate period of time. The system estimates the students' knowledge levels after evaluating the exam. If they achieve the level specified by the teacher, they can move to the other unit. On the exam page, "Question Pass List" shows the questions answered or not answered by the students. They are showed in different colors. Thus, incomplete subjects are identified.

- At the end of the exam, the learning levels of the students are reported to the students through the following expressions: Definitely not known, probably not known, possibly not known, possibly known, probably known, most probably known, and definitely known. The system also lists the units, the pages, and the subjects in which the students have showed a poor performance. Therefore, it guides the students and makes recommendations.

- If students cannot meet the criteria specified by the teacher to pass, the units identified by the teacher cannot be opened since the system prevents it.

- If the students want to take the exam without seeing the pages advised by the system again, the system understands it and prevents the students from doing so by directing them to the pages which should be reviewed again to eliminate the deficiencies. After studying all the pages that should be studied, the students are allowed to take the exam if they want to.

- If the students meet the criteria specified by the teacher as learning level, the system guides the students by offering the information about the units they can move to and activating these units.

- The students and the teacher can view the answers given to the exam questions. The questions answered incorrectly by the students are reported to the teacher.

- The answers given by the students to activity questions are monitored; incorrect answers are identified; and relevant feedbacks are given to the students.

- When the students want to see the subjects they have studied and succeeded in once again, the system provides navigating adaptation. The pages that have been seen by the students are saved as seen pages.

\section{Method}

\subsection{Research Design}

As the purpose of this study was not to make changes on the variables but to reveal the current situation through the data collected by the participants via surveys, a survey method was employed in the study [37]. Survey models are approaches which aim to describe a past or present situation as the way it is. Thus, the event, individual or the object which is the focal point in the study is tried to be defined without any kind of change [38,39].

\subsection{Participants}

The Criterion Sampling was employed in the study while identifying the participants. Criterion Sampling is one of the purposeful sampling methods. Criterion Sampling refers to forming a sample group consisting of people, events, objects or situations with specific characteristics that are previously identified depending on the important criteria for the study [40]. In this study, engaging in a practice with WBITS was taken as a criterion for the pre-service mathematics teachers.

The students attending the mathematics teaching program under the department of elementary education of Kastamonu University were included in the sample group. An experiment was carried out with them in the Physics-I course with a web-based intelligent tutoring system. The experiment with the web-based intelligent tutoring system covered the subject of labor and energy. 60 people participated in the experiment. 60 pre-service mathematics teacher participated in the experiment, out of 43 fit into the focus of study. All the pre-service mathematics teachers who participate in the study had an experience with WBITS when the study was conducted.

\subsection{Data Collection Tools}

In the research, the survey instrument consists of third parts. The first part deals with demographic characteristics (DC) which reveal personal details descriptively. It covers 9 items. In this respect, the study styles, learning styles, and motivation styles of the participants were identified.

The second part consists of 24 items and four factors with the questionnaire developed by İngeç et al. [52]. The scale aims at the identification of pre-service teachers' awareness regarding innovation. The name of the scale is "Innovation Awareness Scale" (IAS). It is a Likert-type scale. "Innovation Awareness Scale" has the following choices: "I strongly agree" (5), "I agree" (4), "I partially agree" (3), "I disagree" (2) and "I strongly disagree". It has 5-point Likert-type rating. IAS consist of four factors, that "Management" dimension factor covers 8 items, "Awareness" dimension factor covers 9 items, "Areas-of-Implementation" dimension factor covers 4 items, and "Defining" dimension factor covers 3 items. The general reliability coefficient of the scale (Cronbach's alpha coefficient) was found to be 0.85 .

The third part covers another Likert-type scale covering 20 items. This second questionnaire included questions to explore participants' perceptions on usability and the influence of WBITS in physics education. The Scale of Views Regarding WBITS was designed by the researchers. 
For the answers to be given to the items, a 5-point Likert-type rating that is frequently used by the researchers was preferred. Accordingly, the rating is as follows: "I strongly agree" (5), "I agree" (4), "I partially agree" (3), "I disagree" (2) and "I strongly disagree" (1). The reliability coefficient of this scale is $\alpha=0.781$. The value refers to an acceptably reliable scale.

\subsubsection{Innovation Awareness Scale}

IAS covers 24 items and four factors. The first factor of the scale called "Defining". It is concerned with the definition of innovation. It focuses on the innovation to reveal whether or not the defined concept. The second factor of the scale called "Areas-of-Implementation" in which area or areas could innovation be used. "Management", the third factor, is concerned with the value and source of innovation. The fourth factor of the scale called "Awareness". It focuses on the knowledge of the innovation's existence. The reliability and validity studies completed. The rate of total variance explained by this structure of the scale is $65.544 \%$. There are 8 items under "management" dimension of the scale which is the first one. Items were rotated via Promax oblique rotation method. Factor load values range from 0.751 to 0.925 . The eigenvalue of this factor is 7.644 , and the rate of the variance explained merely by this factor is $31.851 \%$. The second dimension of the scale involves "awareness". It covers 9 items, and items were rotated via Promax oblique rotation method. Factor load values range from 0.558 to 0.817 . The eigenvalue of this factor is 4.144 , and the rate of the variance explained by the factor is $17.267 \%$. The third dimension of the scale is "areas of implementation" and it covers 4 items. Items were rotated via Promax oblique rotation method. Factor load values range from 0.730 to 0.899 . The eigenvalue of this factor is 2.575 , and the rate of the variance explained by this factor is $10.728 \%$. The fourth dimension of the scale is "defining", and it covers 3 items. Items were rotated via Promax oblique rotation method and factor load values range from 0.660 to 0.752 . The eigenvalue of this factor is 1.368 , and the rate of total variance explained by this factor is $5.698 \%$.

\subsubsection{The Scale of Views Regarding WBITS}

The item analysis of the scale of views regarding WBITS was made through a pilot study, and expert views were taken to ensure validity. In order to ensure validity of the scale, two relevant academic members were consulted, and expert views were received. Internal consistency coefficient was calculated in order to test the reliability of the survey. The general opinion survey covers 20 questions. The first 7 questions cover student views on whether the system provides an enjoyable environment, ease of re-watching, contribution to out-of-class learning, programmed learning environment, ease of access to contents, direction of the courses over web, identification of the subjects involving deficient knowledge, and directing to these subjects (with deficient knowledge). The questions between 8 and 20 in the rating scale are about the characteristics of WBITS. Questions are about intelligence characteristics, integration of personal learning environments to learning activities, conditional transitions between units, not having a limitation of time and place concerning the content, identification of the deficiencies and providing relevant feedbacks, saving the responses, links about relevant subjects, and the contribution of the system to achievement and learning when used in collaboration with in-class education.

\subsection{Data Analysis}

Digital data which were collected through data collection tools were coded and transferred to computer by use of SPSS-21.0. Analyses were carried out based on sub-problems. Descriptive statistics such as frequency, percentage, and cross tabulation were used for analysis of demographic data. Analysis results are given in tables and interpreted.

Shapiro-Wilk test was used to reveal whether or not the scales implemented in the study had a normal distribution. It was seen that views regarding WBITS scores and innovation awareness scores regarding ITS had a normal distribution at 0.05 significance level (view $>0.05$, awareness $>0.05$ ). Therefore, parametric tests were used to analyze the collected data.

Descriptive statistics, a one-way ANOVA and two-way Multivariate Analysis of Variance (MANOVA). were applied to reveal the differences, while Pearson's correlation analysis revealed the relationships when answering the research questions. Prior to main statistical analyses, all the study variables were examined through various SPSS programs for accuracy of data entry, missing values and the assumptions of multivariate analysis. Box's M was used to test for assumption of homogeneity of variance-covariance. Levene's Test was used in order to check that error variance of the dependent variables. Results revealed that dependent variables were normally distributed and the non-significant $F$ tests from Box's M statistics were the sign of homogeneity of variance and covariance matrices $(\mathrm{p}>0.05)$.

\section{Findings}

The findings obtained from the study are presented in accordance with the purposes of the study. Frequency distributions, percentages, mean and standard deviation scores were calculated using the SPSS-21.0.

\subsection{Descriptive Statistics Regarding Demographic Characteristics}

Within the scope of demographic characteristics, gender, learning methods, study styles, learning styles, and motivation styles were explored. The frequency and percentage distributions of the participants are given in Table 
1. $55.8 \%(n=24)$ of the participate in the study were female whereas $44.5 \%$ were male $(n=19) .60 .5 \%$ (26) of the participants had internal motivation while $39.5 \%$ (17) had external motivation. $51.2 \%$ (22) of the participants were visual learners; $25.6 \%$ (10) were auditory learners; and $23.3 \%(10)$ were tactile/kinesthetic learners. As for the study style, $83.7 \%$ (36) reported that they preferred to study individually whereas $16.3 \%$ (7) stated that they preferred to study within a group.

Table 1. Distribution frequency of the participants'/study group's motivation styles, study styles, and learning styles by gender

\begin{tabular}{cccccc}
\hline \multirow{2}{*}{ Variable } & \multicolumn{4}{c}{ Gender } \\
\cline { 3 - 6 } & & \multicolumn{2}{c}{ FEMALE } & \multicolumn{2}{c}{ MALE } \\
\cline { 3 - 6 } & & $\begin{array}{c}\text { Number of } \\
\text { participants }\end{array}$ & $\begin{array}{c}\text { Column } \\
\text { N \% }\end{array}$ & $\begin{array}{c}\text { Number of } \\
\text { participants }\end{array}$ & $\begin{array}{c}\text { Column } \\
\text { Nuny }\end{array}$ \\
\hline \multirow{2}{*}{ Study style } & Individual & 21 & $87.5 \%$ & 15 & $78.9 \%$ \\
& Group & 3 & $12.5 \%$ & 4 & $21.1 \%$ \\
Learning & Visual & 13 & $54.2 \%$ & 9 & $47.4 \%$ \\
style & Auditory & 7 & $29.2 \%$ & 4 & $21.1 \%$ \\
\multirow{2}{*}{$\begin{array}{c}\text { Motivation } \\
\text { styles }\end{array}$} & Tactile & 4 & $16.7 \%$ & 6 & $31.6 \%$ \\
& External & 11 & $45.8 \%$ & 6 & $31.6 \%$ \\
\hline
\end{tabular}

\subsection{Findings Regarding Innovation Awareness}

The lowest score got from "Innovation Awareness Scale" was 53 while the highest one was 93 . Total score average was found to be 70.33 . This result indicates that the innovation awareness of the participants as measured by the 5-point Likert-type scale was 2.93, which refers to the view, "I am neither negative or positive".

Table 2. Arithmetic mean and standard deviation values regarding innovation awareness

\begin{tabular}{|c|c|c|c|c|c|}
\hline & $\mathrm{N}$ & $\bar{X}$ & SD & Level & Interpretation \\
\hline Awareness & 43 & 2.9302 & .42528 & $\begin{array}{l}\text { Neither } \\
\text { negative or } \\
\text { positive }\end{array}$ & Medium \\
\hline Familiarity & 43 & 2.2713 & .30175 & Disagree & Low \\
\hline Defining & 43 & 2.9070 & .70270 & $\begin{array}{l}\text { Neither } \\
\text { negative or } \\
\text { positive }\end{array}$ & Medium \\
\hline $\begin{array}{c}\text { Areas of } \\
\text { implementation }\end{array}$ & 43 & 3.3895 & .91336 & $\begin{array}{l}\text { Neither } \\
\text { negative or } \\
\text { positive }\end{array}$ & Medium \\
\hline Management & 43 & 3.4506 & .59957 & Agree & High \\
\hline
\end{tabular}

SD: Standard Deviation, $\overline{\mathbf{X}}$ : Mean

The arithmetic mean and standard deviation values concerning the participants' innovation awareness are given in Table 2. The score averages of the participants were evaluated within the following categories: "Very Low (1.00-1.79)", "Low (1.80-2.59)", "Medium (2.60-3.39)", "High (3.40-4.19)", "Very High (4.20-5.00)". The awareness of the participants regarding innovation was found to be at "medium" level.

The participants had "medium" level scores for defining innovation and areas of implementation, which are two sub-dimensions of IAS. Another important finding is "high" score average for "management". These findings can be indicative of participants" "neither negative or positive" views regarding innovation awareness.

\subsection{Findings Regarding General Opinions About WBITS}

The lowest score obtained in regard to WBITS' usability and influence on learning was 64 while the highest was 92 . Total score average was found to be 79.79. Accordingly, the participants' general opinions about WBITS as measured in the 5-point Likert-type scale was 3.9895, which refers to the view, "I agree". The arithmetic mean $(\bar{x})$ value of each item was calculated in the Scale of Views Regarding WBITS for the participants. Agreement levels were identified. They are given in Table 3. The mean of the scores in the scale was evaluated in the following categories: "Negative (less than or equal to 1.59)", "Neither negative or positive (1.60-3.40)", "Positive (greater than or equal to 3.41)". The views were examined at $\alpha=0.05$ significance level.

The students using the web-based intelligent tutoring system to learn physic subjects stated that using the web-based intelligent tutoring system over the Internet during their education process had an influence on their learning. As seen in the Table 3, the participants stated with high levels of agreement that the web-based intelligent tutoring system increased success and positively contributed to learning performance though there were some limitations.

The lowest mean score $(3.54 \pm 0.80)$ occurred in the item, "if system is used to support formal education and contribute to out-of-class learning, it will yield much success". The item in response to which the lowest rate of positive opinions emerged (67.4\%) was "Conducting courses by making use of the intelligence of the system made it easier for you to learn". The item which both had the highest mean of score $(4.33 \pm 0.79)$ and the highest rate of positive opinion was "even if the learning environment was much more effective than the real class lectures, it cannot replace face-to-face learning that takes place in classes. However, it contributed to our in-class learning." These findings may indicate that the participants believe that WBITS facilitate learning thanks to WBITS' intelligence, but they cannot replace face-to-face learning.

The participants reported that implementation through the web-based intelligent tutoring system was influential on learning thanks to the feedbacks, the conditions for transitions from one unit to another, saving the responses, the identification of the subjects involving deficient knowledge, the rich content, the web-based access to course content, the links about the subjects, and the presentation of a planned program for the learning environment. 
Table 3. The Results of the General Opinion Survey Regarding Web-based Intelligent Tutoring Systems (WBITS)

\begin{tabular}{|c|c|c|c|c|c|c|}
\hline Items & $\begin{array}{l}\text { Mean } \\
(\bar{X})\end{array}$ & SD & Level & $\begin{array}{l}\text { Negative } \\
\%(\mathrm{f})\end{array}$ & $\begin{array}{l}\text { Neither } \\
\text { negative or } \\
\text { positive } \\
\%(f)\end{array}$ & $\begin{array}{l}\text { Positive } \\
\%(\mathrm{f})\end{array}$ \\
\hline $\begin{array}{l}\text { 1. Teaching physics subjects (labor, energy and conservation of energy) on Internet-based } \\
\text { intelligent system is enjoyable. }\end{array}$ & 4.00 & 1.3274 & High & $9.3(4)$ & 20.9(9) & $69.8(30)$ \\
\hline 2. Re-watching the pages which were previously watched whenever needed facilitates things. & 4.186 & .8798 & High & - & 20.9(9) & 79.1(34) \\
\hline $\begin{array}{l}\text { 3. If system is used to support formal education and contribute to out-of-class learning, it will } \\
\text { yield much success. }\end{array}$ & 3.54 & .7966 & High & - & $11.6(5)$ & $88.4(38)$ \\
\hline $\begin{array}{l}\text { 4. The system's identification of the seen pages, the pages which can be viewed, and the pages } \\
\text { which cannot be viewed contributes to learning by offering a planned program. }\end{array}$ & 3.791 & .8326 & High & $2.3(1)$ & $23.3(10)$ & $74.4(32)$ \\
\hline 5. Contents are designed in such a way that they can be used easily. & 3.953 & .8326 & High & - & $27.9(12)$ & $72.1(31)$ \\
\hline $\begin{array}{l}\text { 6. The system directs students to pages and subjects in which they have had deficiencies. This } \\
\text { is a very good feature contributing to learner performance. }\end{array}$ & 4.186 & .8239 & High & - & $16.3(7)$ & $83.7(36)$ \\
\hline $\begin{array}{l}\text { 7. Following the course on Internet-based intelligent environment enhanced your learning } \\
\text { performance. }\end{array}$ & 4.023 & .8306 & High & - & $18.6(8)$ & $81.4(35)$ \\
\hline $\begin{array}{l}\text { 8. Conducting courses by making use of the intelligence of the system made it easier for you to } \\
\text { learn. }\end{array}$ & 3.814 & .9065 & High & - & $32.6(14)$ & $67.4(29)$ \\
\hline 9. Providing personal learning environments increased your participation in learning activities. & 3.698 & .9889 & High & $4.7(2)$ & $23.3(10)$ & 74.4(32) \\
\hline $\begin{array}{l}\text { 10. Providing feedbacks during the course (marking the subjects to be reviewed) had a positive } \\
\text { influence on your learning. }\end{array}$ & 3,884 & ,9053 & High & - & $23,3(10)$ & $76,7(33)$ \\
\hline $\begin{array}{l}\text { 11. Conditional transitions from one unit to another (end of subject transition questions) } \\
\text { increased our success. }\end{array}$ & 4.000 & 1.023 & High & $4.7(2)$ & $14.0(6)$ & $81.4(35)$ \\
\hline $\begin{array}{l}\text { 12. The questions and activities about the subject provided in the system were richer than those } \\
\text { provided in books and this facilitated our learning. }\end{array}$ & 4.047 & .8985 & High & $2.3(1)$ & $18.6(8)$ & 79.1(34) \\
\hline $\begin{array}{l}\text { 13. Since there was no limit on time and place, more examples and activities were presented } \\
\text { than in the class, which made positive contributions to our learning. }\end{array}$ & 3.884 & .9312 & High & - & $25.6(11)$ & 74.4(32) \\
\hline $\begin{array}{l}\text { 14. According to the answers given to the transition questions, the subjects involving deficient } \\
\text { knowledge were determined by the system, and the system gave feedbacks to study those } \\
\text { subjects once again. This made a positive contribution to our learning. }\end{array}$ & 4.047 & .7222 & High & - & $18.6(8)$ & $81.4(35)$ \\
\hline $\begin{array}{l}\text { 15. Saving the responses and reminding the last page one studied when one logged in } \\
\text { facilitated our learning. }\end{array}$ & 4.186 & .7945 & High & - & $23.3(10)$ & $76.7(33)$ \\
\hline $\begin{array}{l}\text { 16. The animations, links, and figures explaining the relevant subjects in the web-based } \\
\text { intelligent tutoring system enriched our learning environment. }\end{array}$ & 3.953 & 1.0455 & High & $4.7(2)$ & $18.6(8)$ & $76.7(33)$ \\
\hline $\begin{array}{l}\text { 17. The feedbacks regarding the answers given to the activities made positive contributions to } \\
\text { our learning. }\end{array}$ & 4.023 & 1.3361 & High & $7.0(3)$ & $20.9(9)$ & 72.1(31) \\
\hline $\begin{array}{l}\text { 18. Accessing the teacher whenever needed and the feedbacks given by the teacher made } \\
\text { positive contributions to our learning. }\end{array}$ & 3.814 & .9821 & High & $4.7(2)$ & 20.9(9) & $74.4(32$ \\
\hline $\begin{array}{l}\text { 19. When conditions for transitions were fulfilled, the next unit was enabled and activated for } \\
\text { us to learn the relevant subjects, which had a positive reflection on our learning. }\end{array}$ & 3.698 & 1.1027 & High & $7.0(3)$ & $23.3(10)$ & $69.8(30)$ \\
\hline $\begin{array}{l}\text { 20. Even if the learning environment was much more effective than the real class lectures, it } \\
\text { cannot replace face-to-face learning that takes place in classes. However, it contributed to our } \\
\text { in-class learning. }\end{array}$ & 4.326 & .7783 & $\begin{array}{l}\text { Very } \\
\text { High }\end{array}$ & - & $9.3(4)$ & $90.7(39)$ \\
\hline
\end{tabular}

SD: Standard Deviation

\subsection{The Difference between the Pre-service Mathematics Teachers' Views Regarding WBITS and Innovation Awareness by Demographic Characteristics}

Two-way multivariate analysis (MANOVA) was conducted to reveal the differences between the views regarding WBITS and innovation awareness based on pre-service teachers' motivation styles, study styles, and learning styles. Before conducting the two-way multivariate analysis, the assumption of homogeneity of variance was tested. According to Levene's test results, variances were homogeneous regarding innovation awareness $(\mathrm{p}=0.13, \mathrm{p}>0.05)$ and views regarding WBITS. $(\mathrm{p}=.11, \mathrm{p}>.05)($ Table 4$)$.

Table 4. Levene's Test Results

\begin{tabular}{cccccc}
\hline & F & df1 & df2 & p \\
\hline View & 1.707 & 9 & 33 & .127 \\
Awareness & .679 & 9 & 33 & .722 \\
\hline
\end{tabular}

df: Degree of freedom, p: significance value. 
At the end of two-way MANOVA, it was seen that the independent variable of motivation styles did not have a significant influence on innovation awareness $(\mathrm{F}=3.1, \mathrm{p}=0.088, \eta 2=0.0860)$ and views regarding WBITS $(\mathrm{F}=0.122, \mathrm{p}=0.729, \eta 2=0.004)$ [Wilks' Lambda $\lambda=0.914, \mathrm{~F}(2.32)=1.512, \mathrm{p}>0.05, \eta 2=0.086$ ]. In other words, it was accepted that the population averages of the obtained scores did not differ by motivation. $\eta 2$ (eta square) expresses to what extent the multiple variance in the dependent variables is explained by the independent variable[42]. Thus, it was deduced that motivation styles does not have an explanatory effect on the dependent variables since $\eta 2=0.0860$. Two-way MANOVA results regarding the data are given in Table 5.

Table 5. Two-way MANOVA results

\begin{tabular}{|c|c|c|c|c|c|c|c|}
\hline Source & Dependent Variables & SS & df & MS & $\mathrm{F}$ & $\mathrm{p}$ & $\eta^{2}$ \\
\hline \multirow{2}{*}{ Corrected } & View & 523.713 & 9 & 58.190 & 1.740 & .119 & .322 \\
\hline & Awareness & 925.366 & 9 & 102.818 & .983 & .472 & .211 \\
\hline \multirow{2}{*}{ Fixed } & View & 91003.260 & 1 & 91003.260 & 2721,677 & .000 & .988 \\
\hline & Awareness & 63059.988 & 1 & 63059.988 & 603.169 & .000 & .948 \\
\hline \multirow{2}{*}{ Motivation styles } & View & 4.094 & 1 & 4.094 & .122 & .729 & .004 \\
\hline & Awareness & 324.121 & 1 & 324.121 & 3.100 & .088 & .086 \\
\hline \multirow{2}{*}{ Learning style } & View & 139.299 & 2 & 69.650 & 2.083 & .141 & .112 \\
\hline & Awareness & 412.323 & 2 & 206.162 & 1.972 & .155 & .107 \\
\hline \multirow{2}{*}{ Study style } & View & 72.627 & 1 & 72.627 & 2.172 & .150 & .062 \\
\hline & Awareness & 273.209 & 1 & 273.209 & 2.613 & .115 & .073 \\
\hline \multirow{2}{*}{$\begin{array}{l}\text { Motivation styles * } \\
\text { Learning style }\end{array}$} & View & 137.006 & 2 & 68.503 & 2.049 & .145 & .110 \\
\hline & Awareness & 252.717 & 2 & 126.358 & 1.209 & .311 & .068 \\
\hline \multirow{2}{*}{$\begin{array}{l}\text { Motivation styles * } \\
\text { Study style }\end{array}$} & View & 24.008 & 1 & 24.008 & .718 & .403 & .021 \\
\hline & Awareness & 283.500 & 1 & 283.500 & 2.712 & .109 & .076 \\
\hline \multirow{2}{*}{$\begin{array}{l}\text { Learning style *Study } \\
\text { style }\end{array}$} & View & 111.271 & 2 & 55.636 & 1.664 & .205 & .092 \\
\hline & Awareness & 602.383 & 2 & 301.191 & 2.881 & .070 & .149 \\
\hline \multirow{2}{*}{ Error } & View & 1103.403 & 33 & 33.436 & & & \\
\hline & Awareness & 3450.075 & 33 & 104.548 & & & \\
\hline \multirow{2}{*}{ Total } & View & 275389.000 & 43 & & & & \\
\hline & Awareness & 217040.000 & 43 & & & & \\
\hline \multirow{2}{*}{ Corrected Model } & View & 1627.116 & 42 & & & & \\
\hline & Awareness & 4375.442 & 42 & & & & \\
\hline
\end{tabular}

SS: Sum of square, df: Degree of freedom, MS: Mean of square, F: MANOVA result, p: significance value, $\eta^{2}$ : Partial eta squared.

According to the Table 5, there was no significant difference between the study styles [Wilks' Lambda $\lambda=.886$, $\mathrm{F}(2.32)=2.067, \mathrm{p}>0.05, \eta 2=0.0114]$, learning styles [Wilks' Lambda $\lambda=0.781, \mathrm{~F}(4.64)=2.104, \mathrm{p}>0.05, \eta 2=0.116]$, study styles * learning styles [Wilks' Lambda $\lambda=0.762$, $\mathrm{F}(4.64)=2.328, \mathrm{p}>.05, \eta 2=0.127]$, motivation styles * learning styles [Wilks' Lambda $\lambda=0.818, \mathrm{~F}(4.64)=1.688$, $\mathrm{p}>0.05, \eta 2=0.095]$, and motivation styles $*$ study styles [Wilks' Lambda $\lambda=0.913, \mathrm{~F}(2.32)=1.519, \mathrm{p}>0.05, \eta 2=0.087$ ] of the participants as well as their innovation awareness levels and views regarding WBITS. In other words, it was accepted that the population averages of the obtained scores did not differ based on study styles or learning styles. Therefore, it was concluded that neither study styles nor learning styles have an explanatory influence on the dependent variables.

\subsection{The Relationship Between the Views Regarding WBITS and Innovation Awareness}

In order to reveal whether there was a relationship between the participants' views regarding WBITS and innovation awareness, Pearson correlation analysis was conducted. The analysis results are given in Table 6 . Pearson's correlation coefficient was found to be $\mathrm{r}=0.046$. This results indicates no relationship or low relationship which should not be taken into account. The $\mathrm{p}$ value to be used in the significance test for the obtained coefficient was found to be 0.767 . This $\mathrm{p}$ value indicates that the correlation coefficient is not significant. These results may imply that there is no significant relationship between innovation awareness and views regarding WBITS. 
Table 6. The analysis of the correlation between the scores of the participants' views regarding WBITS and innovation awareness

\begin{tabular}{cccc}
\hline & & Awareness & View \\
\hline \multirow{3}{*}{ Awareness } & Pearson Correlation & 1 & .046 \\
& Sig. (2-tailed) & & .767 \\
& $\mathrm{~N}$ & 43 & 43 \\
\hline \multirow{3}{*}{ View } & Pearson Correlation & .046 & 1 \\
& Sig. (2-tailed) & .767 & \\
& $\mathrm{~N}$ & 43 & 43 \\
\hline
\end{tabular}

When each item in the general opinions survey regarding WBITS was analyzed by taking into account the classification of negative, neither negative or positive, and positive views, a differentiation was detected only in the seventeenth item. One-Way ANOVA was carried out to identify differences based on the views. The relevant results are given Table 7 .

Table 7. The influence of innovation awareness on view

\begin{tabular}{ccccccc}
\hline $\begin{array}{c}\text { Source of } \\
\text { Variance }\end{array}$ & $\begin{array}{c}\text { Sum of } \\
\text { Square }\end{array}$ & SD & $\begin{array}{c}\text { Mean of } \\
\text { Square }\end{array}$ & F & p & $\begin{array}{c}\text { Significant } \\
\text { Difference }\end{array}$ \\
\hline Inter-groups & 542.679 & 2 & 271.340 & $10.008 * *$ & .000 & $* 1-2 ; * 1-3$ \\
Intra-groups & 1084.437 & 40 & 27.111 & & & \\
Total & 1627.116 & 42 & & & & \\
\hline
\end{tabular}

SD: Standard Deviation, F: ANOVA result, p: significance value.

$* \mathrm{p} \leq 0.05=$ statiscially significant, $1=$ Negative, $2=$ Neither negative or positive, 3 = Positive.

**The extent of influence was found to be 0.58 .

There was a significant difference between the general opinions about WBITS of the mathematics teachers towards the item, "The feedbacks regarding the answers given to the activities made positive contributions to our learning." by innovation awareness $(\mathrm{F}(2.40)=10.008, \mathrm{p}=0.00)$.

\section{Discussion}

\subsection{Results Based on the Demographic Characteristics of the Pre-Service Mathematics Teachers}

The study results indicate that the pre-service mathematics teachers' views regarding WBITS did not differ by motivation styles. $60.5 \%$ of the participants had internal motivation while $39.5 \%$ had external motivation. External motivation consists of two dimensions which are social motivation tools and organizational tools. Social motivation involves the quality of relationships such as friendship and cooperativeness whereas organizational dimension involves opportunities offered by the organization to increase the work performance [44]. Since the web-based intelligent tutoring system used by the participants provided interactive links, a socially weak learning environment emerged. The use of computers to instruct, the students had lower levels of inter-personal relationships compared to the real class environment. This is believed to reduce the external motivation. Moreover, one of the basic characteristics of WBITS is programmed learning. The purpose is to achieve long-term objectives gradually by completing the short-term objectives. One of the factors of internal motivation is individual objectives. In this sense, it may be thought that WBITS raise internal motivation levels thanks to the individual education and programmed learning environment they provide and thus may positively contribute to learning process, and as a result the motivation styles of the students have an influence on their views regarding WBITS. However, it was seen at the end of the study that motivation style did not have an explanatory influence on the views regarding WBITS. This is a highly remarkable result.

According to the study results, learning style is not a variable having an explanatory influence on the views regarding WBITS. Nearly half of the participants (54.2\%) were identified as visual learners. The interface of WBITS for interaction is computer screen. Since the individuals interact with visual materials and influence during their learning processes, it is possible to think that it may influence their visual learning, which is one of the demographic characteristics. The literature reports that visual technological products influence both the lives and the mental processes of children and young people and change their nature [44,45-47]. WBITS contribute to both using visuals in-depth and accessing course contents over the Internet. Thus, they provide a suitable environment for pre-service teachers who prefer visual learning style. This being the case, the variable of learning style is expected to be influential on views regarding WBITS. However, this expectation is not supported by the study results.

When the participants' views regarding WBITS were explored based on their study styles, no significant difference was observed. About four-fifth of the participants $(83.7 \%)$ were seen to have individual study style. Study style refers to the relationship between the influence and the learner. This creates differences between individual perceptions. Individual differences are classified in three categories which are cognitive, affective, and physiological [48]. These dimensions constitute the study styles of the participants. An individual learning environment is offered in transferring the course content of WBITS which are systems that try to act like teacher, adaptable to student's individual needs and teacher's behavior to participants. Each participant follows the course content based on his/her individual differences for the educational process. They have no problem in timing since there is no limitation. According to the literature, WBITS offer individual interactive learning environments which increase student achievements [49]. Thus, it can be said that it is quite an unexpected finding that the variable of study style has no explanatory influence on the views regarding WBITS.

\subsection{Results Based on Innovation Awareness}

Today, students are expected to possess the 21 st century's learner skills $[19,50]$. "Creativity and innovation" are among 
the ten skills stated in the literature as a must for the 21 st century [27,51]. Therefore, pre-service teachers, who are to play an important role in the education of individuals, are expected to possess such skills. Based on this expectation, this study was carried out to identify innovation awareness levels. In the present study, the innovation awareness of the participants was measured to be 2.93 in the 5-point Likert-type scale, which refers to a "neither negative or positive" view. Moreover, it was seen that the participants did not know about the implementation of the innovation, had difficulty in defining the concept of innovation, were neither negative or positive about the importance of innovative approaches within the education system, and had no clear view regarding R\&D works as a source feeding innovation. Furthermore, they stated that there were no influences to make them aware of innovation. This indicates that the participants did not have awareness, which is considered as the first step of the aforementioned skill. This result is different from some results reported in the literature. Örün et al.[50] conducted a study with 422 pre-service teachers from 12 different departments and four different grades. At the end of that study, the innovativeness profiles of the participants were revealed. That study indicated considerable rates of "being a pioneer" ( $\mathrm{f}=140 ; \% 33.2)$ and "being innovative" ( $\mathrm{f}=31 ; \% 7.3)$. This shows that majority of pre-service teachers possess the "innovative" skill.

Another result regarding innovation awareness is that the participants "highly" acknowledged the importance of innovation for economy, sustainable development, meeting the rising level of employment, transforming knowledge into a social benefit, and raising the society's quality of life.

\subsection{The Relationship Between Innovation Awareness and General Opinions Regarding WBITS}

The views and the opposing views of the pre-service mathematics teachers using WBITS to learn physics subjects in relation to WBITS' usability and influence on learning were explored in the present study. The views of the participants regarding WBITS as measured in the 5-point Likert-type scale was found to be 3.9895 , which refers to "positive" opinions. According to the survey results, the participants generally stated that WBITS increase academic achievement, provide permanent learning by supporting individuality, provide an entertaining and effective learning process thanks to rich visual presentation, but cannot replace face-to-face learning in the real class environment even if it is much more effective than in-class lectures. Moreover, according to the participants, WBITS are also effective during the study process thanks to the feedbacks, the conditions for transitions from one unit to the other, saving the answers, the identification of the subjects involving deficient knowledge, the rich content, access to web-based course content, the links about the subjects, and the programmed learning environment they provide.

Another important result is that no significant relationship was found between innovation awareness and views regarding WBITS. This may be because the awareness levels of the participants were not as expected. Moreover, the participants opined that innovation could be in economic and commercial fields (See Table 5 and Table 6). The participants stated, as seen in the Table 1, that they came across innovation in their educational lives only at a "poor" level and it remained as a concept which they heard in technology stores but could not define. Since they did not know innovation but just had a limited amount of second-hand information about it, no significant relationship could be detected between WBITS and innovation awareness.

\subsection{Recommendations}

Contents, sources, experiences, and technology-based models for creating evaluation systems which can measure student improvement better may be developed in such a way that they encourage students to have innovative approaches. These innovative elements may be integrated into lectures or evaluation processes. Elements such as problems which can lead students to produce new ideas, the ways of making the current situation more convenient, the needs which have never been taken into account before, or answering the same question from different perspectives may be added. The WBITS developed within this context may be tested to see whether or not they are influential on the innovative approaches of students or not.

The present study is limited to WBITS and the labor, energy and conservation of energy subjects of physics course. The learning styles and the study styles of the pre-service teachers are prone to the use of technology. [P4]However, there was no difference between the participants' views regarding WBITS. Conducting studies for different subjects may be beneficial to reveal whether study styles, learning styles, motivation styles, and innovation levels are influential on WBITS.

This study was conducted with pre-service mathematics teachers. Repeating the study with pre-service teachers from different branches and revealing the influence of the implementation on students from different departments may be beneficial.

\section{REFERENCES}

[1] Özarslan, M., Çetin, G., \& Sarıtaş, T. (2013). Biology, physics and chemistry teachers' attitudes toward information and communication technology. Türk Fen Eğitimi Dergisi( Journal Of Turkish Science Education), 10(2), 85-100.

[2] Özkök, A. G. (2013). The design of the creative problem-solving teaching methods in web-based learning environment. Hacettepe University Faculty of Education Journal, Special Issue (1), 287-297 
[3] Walker, S. L., \& Fraser, B. J. (2005). Development and validation of an instrument for assessing distance education learning environments in higher education: The Distance Education Learning Environments Survey (DELES). Learning Environments Research: An International Journal, 8(3), 289-308.

[4] Henderson, D., Fisher, D. L., \& Fraser, B. J. (2000). Interpersonal behaviour, laboratory learning environments, and student outcomes in senior biology classes. Journal of Research in Science Teaching, vol. 37, pp. 26-43.

[5] Fulkerth, R. (2002). Managing for course and program quality in the online environment. Paper presented at the 2002 Teaching Online in Higher Education Conference, Fort Wayne, IN.

[6] Garmston, R. J. (1998). Becoming expert teachers. Journal of Staff Development, 19, 60-63.

[7] Lakshminarayanan, R., Kumar, B., \& Raju, M. (2013). Cloud Computing Benefits for Educational Institutions. Second International Conference of the Omani Society for Educational Technology.

[8] Sarıtaş, M. Tuncay \& Üner, N. (2013). Innovatıve Technologies in Educatıon: Cloud Computıng. Eğitim ve Öğretim Araştırmalart Dergisi (Journal of Research in Education and Teaching), 2(3), 23, 192-201.

[9] Çakır, H.S. (2015). Effects of the use of technology in the learning process efficient method of training. Journal of Research in Education and Teaching, 4(1), 2146-9199.

[10] Halimatou, S., \& Yang, X. (2014) The adoption of instructional techniques and educational technologies among teaching. Creative Education, 5, 2062-2070. doi: $10.4236 /$ ce. 2014.524230

[11] Chigona, Agnes and Chigona, Wallace (2010). An investigation of factors affecting the use of ICT for teaching in Western Cape Town. the 18th European Conference on Information System-ECIS 2010 proceeding, Paper 6.

[12] Al-Ammary, J. (2013). Educational technology: a way to enhance student achievement at the University Of Bahrain. The Online Journal of New Horizons in Education, 7(3), 54-65.

[13] Jonassen, D. H. (1995). Supporting communities of learners with technology: A vision for integrating technology in learning in schools. Educational Technology, 35(4), 60-63.

[14] Steiner,E. (1988). Methodology of Theory Building. Sydney: Educology Research Associates.

[15] Moura Castro, C. (2004). Are new technologies better technologies? For whom? Adapting technology for school improvement: a global perspective. International Institute for Educational Planning. Chapter, 2,. 39-54.

[16] Babette, M., \& Reitzes, T. (2011). Education development center, 1nc. (edc). Integrating technology with student-centered learning. Quincy, MA: Nellie Mae Education Foundation.

[17] Dynarski, M., Agodini, R., Heaviside, S., Novak, T., Carey, N., Campuzano, L., Means, B., Murphy, R., Penuel, W., Javitz, H., Emery, D., \& Sussex, W. (2007). Effectiveness of reading and mathematics software products: findings from the first student cohort. Washington, D.C.: U.S. Department of
Education. Retrieved March 12.

[18] Fadel, C., \& Lemke, C. (2014). Technology in School: What the Research Says.

[19] Trilling, B. ve Fadel, C. (2009). 21st century skills: Learning for life in our times. Jossey-Bass: San Francisco.

[20] Raat, J. H., de Klerk Wolters, F. \& de Vries, M. J. (1987). Report PATT-conference; Vol 1 proceedings (Vol. 1). Eindhoven: Eindhoven University of Technology.

[21] Keswani, B., Banerjee, C., \& Patni, P. (2008). Role of Technology in Education: A 21st Approach.

[22] Gilbert, J. (2007). Catching the knowledge wave: Redefining knowledge for the post-industrial age. Education Canada, 47(3), 4-8. Canadian Education Association.

[23] Reigeluth, C. M., \& Joseph, R. (2002). Beyond technology integration: the case for technology transformation. Educational Technology, July-August, 9-13.

[24] International Society for Technology in Education (ISTE) (2007). The ISTE National Educational Technology Standards $(N E T \cdot S)$ and Performance Indicators for Students. Eugene, OR. Retrieved May 5, 2010 from http://www.iste.org/AM/Template.cfm?Section=NETS

[25] Cabrol, M., \& Severin, E. (2009). ICT to improve quality in education- A conceptual framework and indicators in the use of information communication technology for education. Scheuermann,F. \& Pedró, F.(Ed.). (ICT4E) Assessing the effects of ICT in education: Indicators, Criteria and Benchmarks for international. OECD Press

[26] European Commission. (2011). Garnish with Key Data on Learning and Innovation Through ICT at School in Europe. It was taken on 13.11.2014.

http://sgb.meb.gov.tr/eurydice/kitaplar/Avrupada_bit_aracili gi_ogrenme_ve_yen_uz_temel_ veriler/Avrupada_bit_araciligi_ogrenme_ve_yen_uz_temel_ veriler.pdf.

[27] Binkley, M., Erstad, O., Herman, J., Raizen, S., Ripley, M., \& Rumble M. (2010). Defining $21^{\text {st }}$ century skills. Draft White Paper 1. ATCS, Assessment \& Teaching of $21^{\text {st }}$ Century Skills. The University of Melbourne. Cisco, Intel and Microsoft,1-16.

[28] İmamoğlu, S.Z. \& Açıkgöz, A. (2012). Milli Yenilik Sistemleri ve Türkiye İçin Öneriler (National innovation systems and suggestions for Turkey). Girişimcilik ve Inovasyon Yönetimi Dergisi (Journal of Entrepreneurship and Innovation Management), 1(1), 69-96.

[29] Özmusul, M. (2012). Creativity and innovation in teacher education. Kastamonu Education Journal, 20(3), 731-746

[30] Kağıtçıbaşı, Ç. (2008). Günümüzde Insan ve İnsanlar (Today, on Human and People). Sosyal Psikolojiye Giriş (Introduction to Social Psychology). İstanbul: Evrim Yayınevi.

[31] Hirumi, A. (2014). Does the use of technology improve learning? the answer lies in design. STEM (Science Technology Engineering Math). Retrieved July 09,2014, from https://www.mheonline.com/glencoemath/pdf/technolo gy.pdf

[32] Murray, T. (1998). Authoring Knowledge Based Tutors: 
Tools for Content, Instructional Strategy, Student Module and Interface Design. Journal of the Learning Sciences, 7(1), 5-64.

[33] Graesser, A. C., Conley, M. W. \& Olney, A. (2012). Intelligent Tutorıng Systems. Educational Psychology Handbook 3nd ed., Graham, S., Harris, K., American Psychological Association, Washington, 452.

[34] Moundridou, M., \& Virvou, M. (2000). A web-based authoring tool for algebra-related intelligent tutoring systems. Educational Technology \& Society, 3(2), 61-70.

[35] Doğan, N., \& Kubat B. (2008). Ak1llı öğretim sistemleri için yeni bir bileşen: düzenleyici modül. Bilişim Teknolojileri Dergisi, 1(2), 5-9.

[36] Yılmaz, F., Soğukçeşme, G., Ayhan, N., Tuncay, S., Sancar, S., \& Deniz, Y. M. (2014). The department of primary education teachers of professional innovation trends in the study of different variables. University Journal of Graduate School of Social Sciences, 11(27), 259-276.

[37] Fraenkel, J. R., Wallen, N. E., \& Hyun, H. H. (2012). How to design and evaluate research in education (8th ed.). New York: Mc Graw-Hill Companies

[38] Fraenkel, J., R., \& Wallen, N. E. (2006). How to design and evaluate research in education. (6th Edition). New York: McGraw-Hill Book Company.

[39] Büyüköztürk, Ş. (2009). Veri analizi el kitabı (Data analysis handbook). Ankara: Pegem Akademi Yayınları.

[40] Büyüköztürk, Ş., Kılıç-Çakmak, E., Akgün, Ö.E., Karadeniz, Ş., \& Demirel, F. (2011). Bilimsel araştırma yöntemleri (Scientific research methods) (8th edition). Ankara: Pegem Press.

[41] İstanbul, A. (2003). Software development for biomedical engineering education. Unpublished $\mathrm{PhD}$ Thesis, Gazi University Graduate School of Natural and Applied Sciences, Ankara.

[42] Shieh, G. (2013). Confidence intervals and sample size calculations for the weighted eta-squared effect sizes in one-way heteroscedastic ANOVA. Behavior Research Methods, 45(1), 25-37.

[43] Altok, T. (2009). A Comparative Study on Employee Motivation Factors Affecting Services Related to Manufacturing Or Business. Master's thesis. Süleyman Demirel University Institute of Social Sciences, Isparta.

[44] Bleed, R. (2005). Visual literacy in higher education. [Online]: Retrieved on 17 October-2007, at URL: http:// www.educause.edu/ir/library/pdf/ELI4001.pdf.
[45] Lowe, R. (2000). Visual literacy in science and technology education. International Science, Technology and Environmental Education Newsletter, 15(2), 1-4.

[46] White, M. A. (1987). Information and imagery education. In M. A. White (Ed.), What Curriculum for the Information Age? Hillsdale, NJ: Erlbaum.

[47] Akpınar, B. (2009). Primary 1-5. classes Turkish curriculum assessment of visual reading and learning area presentation. Eğitim ve Bilim (Education and Science), 34(154), 37-49.

[48] Ekici, G. (2003). Öğrenme Stiline Dayalı Öğretim ve Biyoloji Dersi Öğretimine Yönelik Ders Planı Örnekleri (Towards Teaching and Learning Styles Based Language Teaching Biology Curriculum Samples). Gazi Kitabevi. (1st edition), Ankara

[49] Erdemir, M. \& İngeç Kandil, Ş. (2014). Physics Teaching in Web-Based Intelligent Tutoring System (WTITS) Impact on Success. Journal of Research in Education and Teaching , 3(1), 28.

[50] Örün, Ö., Orhan, D., Dönmez, P., \& Kurt, A. A. (2015). Individual analysis of the relationship between teachers and technology innovation profile attitude levels. Trakya Üniversitesi Eğitim Fakültesi Dergisi (Journal of Trakya University Faculty of Education), 5(1), 65-76.

[51] ATEE. (2007). Response from the Association for Teacher Education in Europe (ATEE) to the Public Consultation on Schools for the 21st Century. pp:4 http://www.atee1.org/publications/3/response_to_the_commi ssion $039 \mathrm{~s}$ public cons ultation on schools for the_21st_century.

[52] İngeç, Ş.K., Akyol, K., Özcelik,E., Bolat, T. \& Alkan,E. (2015). Öğretmen Adaylarının İnovasyon Farkındalık Duzeylerinin İncelenmesi. 21. Yüzyılda Eğitim Politikaları: Kanıt, araştırma, inovasyon ve değer (Educational Policy in the 21 st Century: Evidence, Research, Values \& Innovation), 28-31 May, Muğla.

[53] Doğan, N. \& Kubat, B. (2008). Bilişim teknolojileri dergisi, $1(2), 5-9$.

[54] Erdemir, M., İngeç, Ş.K. \& Karacı, A. (2016). Student Vıew On Web-Based Intelligent Tutoring Systems About Success And Retention of Physics Education. International Journal of Managing Public Sector Information and Communication Technologies (IJMPICT), 7(2), 1-8.

[55] Melis, E. \& Siekmann, J. (2004). ActiveMath: An Intelligent Tutoring System for Mathematics. Seventh International Conference 'Artificial Intelligence and Soft Computing (ICAISC). L. Rutkowski and J. Siekmann and R. Tadeusiewicz and L.A. Zadeh (eds), Springer-Verlag, 91-101. 